\title{
Beating Round the Bush!
}

\author{
Ahmed N Ghanem* \\ Consultant Urological Surgeon, Egypt
}

ISSN: 2578-0379

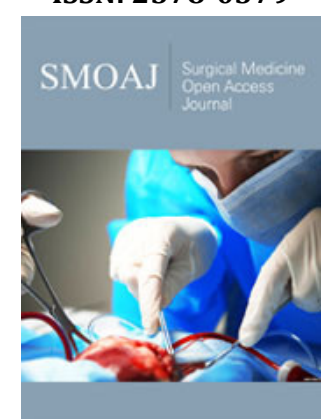

*Corresponding author: Ahmed N Ghanem, Consultant Urological Surgeon, Egypt

Submission: 非 April 29, 2019

Published: 漈 May 6, 2019

Volume 2 - Issue 4

How to cite this article: Ahmed $\mathrm{N}$ Ghanem. Ahmed N Ghanem. Surg Med Open Acc J.2(4). SMOAJ.000543.2019. DOI: 10.31031/SMOAJ.2019.02.000543.

Copyright@ Ahmed N Ghanem, This article is distributed under the terms of the Creative Commons Attribution 4.0 International License, which permits unrestricted use and redistribution provided that the original author and source are credited.

\section{Editorial}

Having read with interest Richard Smith's editorial based on the BMJ survey and the lively debates on "Why are doctors so unhappy?" [1], one wonders if the roots of the problem and its solution remain overlooked while all are just beating round the bush. What has been said so far may have just succeeded in identifying the ill effects and manifestations of the problem: unhappy sick profession and discontented public with a falling apart MOH that was once one of the prides of the British system.

I believe all doctors owe it to a single man who has identified and addressed the real problem. So, I am asking all: "Hats off, please, and bow to this man" Professor Fischer et al. [2] who has the courage to tell the bitter truth about the current status of medicine in USA. He has not only given a personal perspective but also an inside witness's account that audit the system of "Phase 1 managed care", marking the historical demise of such a failure system that succeeded in nothing but making such unhappy profession and discontented public worldwide.

Should the editor of this journal kindly approve publication of only these lines i should be most content and grateful, having expressed my support and admiration to the author and brought the fact to the attention of those concerned. However, there are further comments one wishes to make, if allowed. I do not just give verbal vote of support to Professor Fischer et al. [2] but also believe one took a stand similar to that of "Dick" on smoking without daring to use a word he once introduced and twice used.

Soon after implementing the system in UK and realizing what it aimed at in 1988, I did not only leave $\mathrm{MOH}$ but also opted for elective removal from the full registration records of the General Medical Council. It was with sadness to learn, a few years later, that most of the best consultants, who taught me most medicine and surgery I know, had also opted for early retirement at the age of 55 years. This was just to avoid the hassle of the failure system. What a waste of most concern is Professor Fischer's estimation that it may take decades in USA for the old system to be, if ever, restored. I pray for the countries that faithfully followed USA, wondering how long it may take to realize that the system has been proved a failure. I decline to estimate how long it may take some other countries to restore the old health care system or install a better one.

The only foreseen optimism for a rapid change may come from a rather an unexpected paradox: the self-appointed economists who implemented and managed the failure system may wish, instead of persisting, to run for cover before impending law suits catches them in USA and is sure to follow elsewhere. No doubt they all will try to justify their errors by governments' policies, but this may not work.

The discontented public and unhappy doctors [2] have already realized that providing a quality healthcare (and education) are Nation's best investments, in which every professional has a job to do: the medical professionals to provide the health care, managers to sort out 
the public's and workers' problems, economists to insure adequacy of supplies and raise funds necessary for it. Should the economic measures mentioned by Professor Fischer prove insufficient, one can think of one or two obvious sources for increasing the required funds- without increasing taxes.

\section{References}

1. Richard Smith (2015) Why are doctors so unhappy? BMJ 322(7294): 1073-1074.

2. Fischer JE Matter (2001) Current status of medicine in the USA: a personal perspective. J R Coll Surg Edin 46(2): 71-75.

For possible submissions Click below: 